\title{
集団的健康指導法よりみた冠危険因子
}

$\begin{array}{lll}\text { 日野原茂雄 } & \text { 滝脇 } & \text { 収二 } \\ \text { 高下恵美子 } & \text { 崎田 } & \text { 隆一 } \\ \text { 上 村 等 } & & \end{array}$

〈目的〉われわれは従来より，健診のコンピュー 夕を用いて集団的なリスクアセスメントであるカンパ ニイ・プロファイルス，あるいは健康度レベル図を作 成し，これをポスターとして提供し，企業の集団的健 康指導を試みております。今回はこのポスターをより 理解しやすい方向に改善することを目的に検討し，併 せて受診者の冠危険因子所有状況の推移を検討し, 多 少の興味ある知見を得ましたので報告致します。

〈対 象〉対象は当院健診センターにおいて自動化 総合健診を受診した 30〜 59 歳の男性のみであります。 受診者数は, 1987 年度が 8,111 名, 1988 年度は 8,988 名でありました。なお，カンパニイ・プロファイルス は前年度迄は企業 11 社を対象として作成してまいり ましたが， 88 年度は見直しを行い，対象者数が 150 名以上の 10 社に変更致しました。また, 前年度まで は冠危険因子 12 項目について，ヘルススコアを指標 としてプロファイルスを作成しましたが，実際に使用 してみますとやや難解と考えられましたので 88 年度 はリスクスコアを指標とすることと致しました。また， これまでは冠危険因子 12 項目のカンパニイ・プロファ イルス 12 枚を 1 枚のポスターに表示してきましたが， 88 年度はこれを 9 項目のみとして 9 枚に絞り, 個々の カンパニイ・プロフィールを大きく表示するように致 しました。なお，危険因子の集計には，NECのコンピ ュータ ACOS 410 を用いました。

〈成 績〉 88 年度に新たに対象として加わった企 業は 1 社のみであり, 脱落した企業は 2 社でありまし た。企業毎のリスクコア所有率を表示する方法は，へ ルススコア所有率を表示する方法に比較して，より理 解しやすいとの印象が得られました。カンパニイ・プ ロファイルスを 12 項目から 9 項目に削減し, 個々のプ ロフィールを拡大したことも同様にポスターを理解し やすくしたものと考えられます。前年度は 2 年分の健
高橋 為生 関谷 清美

岡本 平次 藤森 一平

康度レベル図を重ねて，年度間の比較ができるように しておりましたが, 88 年度はこの比較図を削除し, 代 わりに健康度分類図を載せました。この点に関しまし ては,いずれの方がよいのか現在も検討中であります。 なお，最近ではポスターの発送が遅れますと，約半数 の企業から催促が寄せられるようになっておりますの で，本指導法が企業に定着しつつあるものと考えられ ます。

企業毎の冠危険因子所有状況につきましては，先ず 最も成績の良い企業と最も成績の悪い企業との開き幅 を検討致しました。開き幅の大きかった項目は両年と も共通で喫煙, 飲酒, 運動, A 型行動性格, 肥満など の項目であり，また 2 年の間でこの開き幅の動きが大 きかった項目は喫煙, 運動, 肥満, 血清総コレステロ ール，尿酸などでありました。

全般的な印象では，例年のごとく，成績の良い企業 は相変わらず上位に位置し，成績の悪い企業は相変わ らず下位に位するという現象が今回もみられました。 個々の企業に関する冠危険因子所有率は, 例えば前年 度最良であった企業 10 をみますと僅かながらさらに 改善を示し, その他の企業 270,320 なども今年度は明 かな改善を示しておりました。最後に 30〜 59 歳の受 診者全員 (Overall) の冠危険因子所有率を前年度と比 較致しましたが，今年度は 12 項目のうち肥満を除く 全項目で改善が認められました。

〈結 論〉以上の様に改良をおこなってみますとポ スターは予想以上に見やすく改善されたと考えられま した。したがって今後もさらに改良を加えていく必要 がありましょう。また，企業の冠危険因子所有率の検 討では，企業間で開きの大きい項目，あるいは年度間 で動きの大きい項目などが明かとなりました。これら は特に指導効果が期待される項目と考えられました。

\section{Effect of Group Health Education by Company Profiles on Coronary Risk Factor in AMHTS}

東海大学病院健診センター 